\title{
PENGARUH RELAKSASI OTOT PROGRESIF TERHADAP KECEMASAN PADA WANITA PASANGAN USIA SUBUR (WPUS) PENDERITA HIV/AIDS
}

\author{
${ }^{1)}$ Novie E. Mauliku, ${ }^{2)}$ Siti Nur Endah ${ }^{3)}$ Sri Yuniarti \\ Stikes Jenderal Achmad Yani Cimahi \\ Jl. Terusan Jenderal Sudirman Cimahi - Jawa Barat - Indonesia \\ E-mail: ${ }^{1)}$ noviemauliku@ gmail.com, ${ }^{2)}$ sitinurendahhendayani@gmail.com, \\ 3) sriyuniartispi@yahoo.com
}

\section{Kata Kunci:}

Terapi relaksasi, Otot progresif, Kecemasan,ODHA, HIV/AIDS

\section{ABSTRAK}

HIV /AIDS adalah penyakit infeksi yang menyerang sistem kekebalan tubuh. Kasus HIV/AIDS masih menjadi salah satu maslah kesehatan di dunia, karena tren penyakit yang masih meningkat. Stigma negatif dan diskriminatif dapat memberikan tekanan psikologis yang tinggi dan rasa cemas. Rasa kecemasan yang berlebih pada ODHA akan menyebabkan perasaan tidak pasti, merasa bersalah, depresi, dan tidak berdaya, gelisah, fobia, ilusi dan halusinasi, sehingga mempengaruhi kualitas hidup ODHA. Tujuan penelitian adalah mengetahui pengaruh terapi pengenduran/relaksasi otot progresif terhadap kecemasan wanita usia subur (WPUS) penderita HIV/AIDS. Metode penelitian yang digunakan adalah kuasi eksperimen one-group pretes-postes desain . Responden adalah penderita HIV/AID sebanyak 10 orang. Data diperoleh menggunakan HARS dan dianalisis dengan t-dependen pada pemaknaan 0,05 (CI 95\%). Hasil penelitian menunjukkan indeks kecemasan awal sebesar 29,90 (cemas berat), sedangkan setelah relaksasi menjadi 16,50 (cemas ringan). Hasil analisis statistik didapatkan terdapat pengaruh relaksasi otot progresif terhadap kecemasan WPUS penderita HIV/AIDS (pValue=0.000). Diharapkan relaksasi otot progresif dapat menurunkan tekanan psikologis WPUS penderita HIV/AIDS melalui penyuluhan kesehatan dan demonstrasi gerakan terapi relaksasi otot progresif.

Keywords:

Relaxation therapy,

Progressive muscle, anxienty, HIV/AIDS

\section{Info Artikel}

Tanggal dikirim: 08-03-2021

Tanggal direvisi: 27-3-2021

Tanggal diterima: $21-07-2021$

DOI Artikel:

10.36341/jomis.v5i2.1723

Creative Commons Attribution-

NonCommercial-ShareAlike 4.0 International License.

\section{ABSTRACT}

HIV/AIDS is an infectious illness that assaults the insusceptible system. HIV/AIDS cases are as yet one of the medical issues in the world, because the disease trend is still increasing. Negative and discriminatory stigma can lead to high psychological stress and anxiety. Excessive anxiety to PLWHA will cause feelings of uncertainty, guilt, depression, and helplessness, anxiety, phobias, illusions and hallucinations, thus affecting the quality of life of PLWHA. The aim of the study was to determine the impact of progressive muscle relaxation on the anxiety of women of childbearing age with HIV/AIDS. The research method used a quasi experimental one-group pretestposttest design. Respondents were 10 people with HIV/AIDS. Data were obtained using HARS and analyzed by t-dependent at a significance of 0.05 (95\% CI). The outcomes showed the initial anxiety index was 29.90 (severe anxiety), while after relaxation it was 16.50 (mild anxiety). The results of statistical analysis showed that, there was an impact of progressive muscle relaxation on the anxiety of WPUS sufferers of HIV / AIDS (p Value = 0.000). It is hoped that progressive muscle relaxation can reduce the psychological pressure of WPUS sufferers of HIV/AIDS through health education and demonstration of progressive muscle relaxation therapy movement. 


\section{PENDAHULUAN}

Human Immunodefiency Virus/aquired Immuno Deficiency Syndrom (HIV AIDS) adalah penyakit infeksi yang menyerang sistem imun tubuh. Kasus HIV AIDS masih menjadi prioritas masalah yang harus ditanggulangi, karena selalu karena selalu mengalami peningkatan setiap tahunnya. Berdasarkan Data WHO tahun 2017 diketahui bahwa dari 36,9 juta penderita HIV AIDS, terdapat 1,8 juta kasus baru. Jumlah kumulatif Kasus HIV/AIDS pada akhir Juni 2020, dilaporkan sebanyak 38 juta manusia di dunia terinfeksi HIV tahun 2019, dengan 1,7 juta kasus HIV baru dengan 690 ribu kasus kematian $^{[1], ~[2] . ~ J u m l a h ~ k a s u s ~ k u m u l a t i f ~ H I V ~}$ AIDS di Indonesia pada tahun 2017 adalah sebesar 280,623 dengan kumulatif kasus AIDS adalah 48,300. Sedangkan pada tahun 2019, diketahui jumlah kasus HIV AIDS adalah 394.769 dengan kasus baru sebesar 50.282 kasus [1], [2]. Provinsi Jawa Barat menempati peringkat ke-4 di Indonesia, dengan total kasus HIV 23,145 dan AIDS sebesar 5,251 ${ }^{[2]}$.

WPUS adalah wanita yang menikah dengan rentang usia antara 15 sampai 49 tahun, usia kurang 15 tahun dan sudah menstruasi, serta berusia $\geq 50$ tahun tetapi masih menstrulasi ${ }^{[3]}$. WPUS, memiliki risiko yang tinggi untuk terinfeksi HIV. Berdasarkan hasil penelitian, penyebab terjadinya peningkatan kasus pada WUS adalah dikarenakan hubungan seksual dini, pasangan lebih dari satu dan tidak mengetahui status kesehatan pasangannya yang terinfeksi ${ }^{[4]}$. Penelitian Oktaseli (2017) menyebutkan bahwa wanita pasangan usia subur (WPUS) dengan HIV/AIDS menjadi semakin rumit dan rentan untuk merasa cemas serta minder jika berbaur dengan orang disekitarnya, bahkan mereka merasa takut ketika bertemu dengan orang baru dan lebih cenderung mengurung diri dengan keadaan yang dideritanya ${ }^{[5]}$.

Beijing Platform for Action (BPFA), menyebutkan konsekuensi HIV/AIDS mempengaruhi kesejahteraan perempuan dalam peranannya sebagai ibu dan wali serta komitmennya dalam membantu keuangan keluarga, bertanggungjawab untuk melahirkan anak, dan menyelesaikan pekerjaan rumahan. Jika seorang perempuan terinfeksi HIV/AIDS, maka ekonomi keluarga lemah, dan kualitas fisik dan mental anak yang dilahirkan akan buruk,

Terjadinya HIV AIDS sebagai salah satu penyakit menular kronis, selain menyebabkan gangguan fisik juga mempengaruhi pada kehidupan sosial Orang Dengan HIV AIDS (ODHA $)^{[6]}$. Kematian, stigma negatif dan diskriminatif dapat memberikan tekanan psikologis yang tinggi dan rasa cemas. Rasa kecemasan yang berlebih pada ODHA akan menyebabkan perasaan tidak pasti, merasa bersalah, depresi, dan tidak berdaya, kegelisahan, fobia, ilusi dan halusinasi, sehingga mempengaruhi kualitas hidup ${ }^{[7],[8][9]}$.

Kecemasan merupakan kondisi kerentanan psikotik, ketidak stabilan, dan kekurang mampuan menghadapi tantangan dan tekanan hidup ${ }^{[10]}$. Untuk menghindari dampak yang ditimbulkan dari kecemasan ini, maka salah satu caranya adalah dengan memberikan terapi non farmakologis, sepeerti terapi fisik (yoga, pijat), Teknik relaksasi (miiditasi, visualisasi, hipnoterapi, dan relaksasi otot progresuf), dan pengobatan dengan obat herbal.

Relaksasi otot progresif, merupakan pelepasan otot reformis adalah prosedur peregangan otot yang mendalam dan tidak membutuhkan pikiran, ketekunan atau ide 
kreatif. Pelepasan ini tergantung pada keyakinan bahwa tubuh manusia bereaksiterhadap ketidaknyamanan dan kejadian-kejadian awal otak akibat tekanan otot. Saat melakukan perawatan pelepasan otot reformis, terjadi peregangan kardiopulmoner yang dapat membangun baroreseptor yang menghidupkan saraf parasimpatis dan menahan focus perhatian yang memperluas saraf parasimpatis yang akan mengurangi ketegangan, dan mengontrol kapasitas denyut jantung sehingga tubuh rileks ${ }^{[11]}$.

Mark and Barlow (2009) mengemukakan bahwa gejala cemas dan tegang pada individu dapat diatasi dengan cara melakukan Teknik pengenduran otot. Sebagaimana hasil penelitian Rihiantoro (2018), WPUS yang melakukan latihan relaksasi progresif selama 2 kali dalam sehari mengalami cemas ringan sebesar $73 \%$ dan cemas sedang sebesar $27 \%^{[12]}$. Penelitian lainnya menyatakan bahwa terapi yang dilakukan selama 1 hari yaitu di pagi dan sore hari pada responden dengan cemas ringan dan cemas sedang mengalami penurunan dan bahkan tidak mengalami kecemasan [13]. Merujuk latar belakang diatas, maka penelitian bertujuan menelaah pengaruh relaksasi otot progresife terhadap kecemasan Wanita Pasangan Usia Subur (WPUS) penderita HIV/AIDS.

\section{TINJAUAN PUSTAKA}

Kecemasan adalah reaksi individu yang secara umum bersifat negatif dan cenderung mengancam. Menurut Kaplan dan Sadock (1998), gejala fisik timbulnya kecemasan meliputi peningkatan denyut jantung, palpasi, berkeringat, fenomena raynaund, diare, dan sering buang air kecil (BAK), gangguan pencernaan, dan kehilangan nafsu makan. Sedangkan indikasi mental meliputi ketidakberdayaan, rendah diri, kehilangan kepercayaan, kesulitan berkonsentrasi, ketakutan dan insomnia ${ }^{[14]}$.

Kecemasan dapat terlihat langsung melalui perubahan fisiologis dan perilaku secara implikatif melalui indikasi awal atau cara mengatasi stress dalam mempersiapkan diri dari rasa cemas. Respon fisiologis yang muncul dari timbulnya kecemasan, adalah palpatisi, jantung berdegup kencang, tekanan darah meningkat/menurun, nafas cepat dan dangkal, rasa tertekan didada, pembengkakan daerah tenggorokan, refleks meningkat, mudah terkejut, insomnia, gelisah, kehilangan nafsu makan, rasa tidak enak pada bagian perut disertai mual, sakit, dan mencret, beser, wajah kemerahan, serta berkeringat berlebih. Gejala prilaku ditunjukkan dengan gelisah, ketegangan fisik, tremor, gugup, dan cenderung afatis dengan lingkungan sekitar. Dari segi kognitif, yaitu perhatian terganggu, konsentrasi hilang, pelupa, salah mengambik keputusan, mimpi buruk, kebingungan, dan kreativitas-produktivitas menurun ${ }^{[15]}$.

Dadang Hawari (2006), mengemukakan bahwa terjadinya kecemasan pada seseorang diantaranya rasa khawatir, tidak tenang, ragu, dan bimbang; tidak percaya diri, sering merasa bersalah atau cenderung menyalahkan orang lain, sering mengeluh, dan terkadang emosi yang tidak stabil dan bahkan histeris ${ }^{[16]}$. Begitupula halnya dengan ODHA, mereka akan mengalami kecemasan akan membawa efek psikologis yang mendalam, malu, memiliki rasa ingin bunuh diri. Mengingat besarnya dampak kecemasan yang ditimbulkan maka diperlukan upaya untuk memenej perasaaan kecemasan tersebut.

Tingkat kecemasan yang dialami seseorang dapat dikategorikan menjadi kecemasan ringan adalah ketegangan dalam 
menghadapi kehidupan sehari-hari yang berakibat individu berhati-hati dan merubah persepsinya. Kecemasan sedang, menyebabkan lapangan persepsi individu menyempit, dan perhatian terhadap rangasangan berkurang. Kecemasan berat, persepsi individu berfokus pada hal keil, rinci dan spesifik. Sedangkan panik merupakan kecemasan yang ekstrim karena individu telah kehilangan kendali dan tidak mampu menerima arahan ${ }^{[17]}$.

Relaksasi otot progresif adalah peregangan/pengenduran otot yang mengalami ketegangan. Relaksasi otot progresif akan mempengaruhi hipotalamus dan menurunkan kerja sistim syaraf simpatik melalui saraf parasimpatis $^{[18] .}$ Perubahan fisiologis tubuh setelah melakukan relaksasi otot, diantaranya menurunnya tekanan darah, penurunan frekuensi gerka jantung dan pernafasan, serta mengurangi ketegangan otot,. Relaksasi otot akan mempengaruhi gama amino butyric acid (GABA) yeng menghambat neurotasmiter di otak. Stimulus ini akan menyebabkan persilangan sinaps, yang mempengaruhi membrane postsinap dan membuat resptor terbuka diikuti oleh pertukaran ion, sehingga tidak terjadi stres atau kecemasan ${ }^{[19]}$. Terapi ini merupakan terapi termurah, tanpa bimbingan, imajinasi, mudah dilakukan secara mandiri dengan waktu yang relative singkat.

Hasil penelitian Ambarwati, dkk (2020), menunjukkan bahwa penerapan relaksasi otot progresif pada pasien asma bronchial menyebabkan menurunnya kecemasan dari sedang menjadi normal atau tidak cemas ${ }^{[20]}$. Hasil penelitian Lestiawati (2019), menjelaskan bahwa tehnik relaksasi otot progresif dan autogenic yang diberikan kepada remaja, efektif menurunkan tingkat stress ${ }^{[13]}$. Hasil penelitian Julianti (2017) pada pasien spasmofilia di RSUP Dr.
Karyadi, menyatakan bahwa aktivitas pengenduran otot progresif memperbaiki gejala mental dan harapan hidup pasien ${ }^{[21]}$. Dan menurut hasil penelitian Lestari, dkk (2015) memperlihatkan bahwa relaksasi otot progresif mempengaruhi skala cemas pasien preoperasi ${ }^{[11]}$. Aprilya, dkk (2015) meneliti tentang pelatihan relaksasi untuk menurunkan kecemasan dalam delapan sesi selama kurang lebih dua minggu menunjukkan adanya selisih yang signifikan pre dan post intervensi ${ }^{[22]}$.

\section{METODE}

Desain penelitian menggunakan pendekatan quasi eksperimen $^{[23]}$. Penelitian ini dilakukan dengan mengukur kecemasan sebelum intervensi, dan melakukan pengukuran ulang setelah intervensi, dengan rancangan one group pre test - pos test, dengan skala kecemasan Hamilton Rating Scale (HARS). HARS telah dilakukan uji validitas dan realibilitas dengan score $\mathrm{r}=0,57-0,84$ sehingga dapat diterapkan dalam penelitian ini. Skala HARS adalah proporsi kegugupan yang bergantung pada adanya indikasi yang muncul pada diri sesertang. Setiap item diobservasi dengan rentang skor $0-4(0=$ tidak ada efek samping; 1 = indikasi ringan; $2=$ manifestasi sedang; $3=$ berat, dan $4=$ serius). Instrumen estimasi ini terdiri dari 14 kumpulan tanda yang diuraikan menjadi tidak cemas, ringan, sedang, berat, dan panik.

Intervensi yang diberikan kepada responden sejumlah 2x dalam satu hari yakni dini hari dan sore, dengan durasi 10-15 menit selama 3 hari berturut turut. Pengukuran HARS dilakukan sebelum terapi dan pada akhir terapi.

Populasi adalah seluruh wanita pasangan usia subur penderita HIV/AIDS di Klinik Mawar Kota Bandung sebanyak 10 responden yang diambil secara total sampling. Analisis data 
dilakukan secara deskriptif dan diuji dengan T-dependen dengan taraf signifikasi 0.05 (CI $95 \%)$.

\section{HASIL DAN PEMBAHASAN}

\section{Rata-rata kecemasan WPUS penderita HIV/AIDS sebelum intervensi}

Tabel. 1 Pengukuran kecemasan sebelum terapi

\begin{tabular}{lcc}
\hline Kecemasan & Frek. & $\%$ \\
\hline Berat & 7 & $70 \%$ \\
Sedang & 3 & $3 \%$ \\
\hline Total & 10 & $100 \%$ \\
\hline
\end{tabular}

Pengolahan data secara deskriptif, menunjukkan tingkat kecemasan responden sebelum dilakukan terapi, $70 \%$ mengalami kecemasan berat. Kecemasan berat pada umumnya akibat tekanan menghadapi tantangan dalam kehidupan yang membuat individu berhati-hati dan meninggikan area pemahamannya. Sebagaimana teori yang dikemukana oleh Beck A.T dan Emery C (1985), bahwa respon fisik individu ketika mengalami kecemasan, adalah tegang otot, ttv meningkat, pupil dilatasi, berkeringakt, mondar mandir, meremas tangan, intonasi suara berubah, bergetar, sering buang air kecil, pola tidur berubah, dan secara kognitif persepsi, penyelesaian masalah, dan perhatian pembelajaran menurun ${ }^{[9]}$.

Berdasarkan hasil wawancara kepada responden, kecemasan mereka didasarkan pada ketakutan akan menularkan penyakit tersebut kepada keturunannya (anak), kecemasan akan kesembuhan dari penyakit, perasaan sensitif berlebihan, perasaan tidak terbuka dan stigma masyarakat membentuk negatif thinking pada individu responden. Selain itu mereka pun merasakan sakit dan nyeri di otot, kedutan dan kaku otot ketika mengalami stress, tinnitus, penglihatan kabur, perasaan ditusuk tusuk, nyeri dada, denyut nadi mengeras, tidak nafsu makan dan gangguan pencernaan, serta beser.

Seorang ibu rumah tangga dalam hal ini WPUS yang terkena HIV/AIDS pada umumnya berpendidikan rendah dan tidak memiliki informasi yang memadai tentang konsep kesehatan reproduksi termasuk di dalmnya mengenai HIV/AIDS. Bahkan beberapa WPUS beranggapan bahwa penyakit yang diidentikkan dengan reproduksi merupakan suatu hal yang sangat tabu untuk diungkapkan. Selain dari pada itu, WPUS selalu menomorduakan kesehatannya dibandingkan dengan kesehatan anggota keluarganya, sehingga ketika dirasakan sakit perempuan cenderung diam dan tetap lebih memperhatikan anggota keluarga lainnya.

Hasil penelitian Dewi, dkk (2019), Wanita Pasangan Usia Subur (WPUS) cenderung rentan untuk mengalai cemas dan kurang percaya diri untuk berbaur dengan orang lain yang berada disekelilingnya, timbulnya keseganan ketika bertemu dengan teman baru, sehingga mereka akan bersifat afatis dengan kondisi yang dialaminya. Situasi ini semakin diperparah dengan sosial budaya masyarakat yang selalu menempatkan perempuan mempunyai posisi di bawah laki-laki, yang mengakibatkan perempuan diperlakukan tidak adil, apalagi mereka yang terinfeksi oleh HIV/AIDS walaupun dari suaminya sendiri ${ }^{[24]}$.

\section{Rata-rata kecemasan WPUS penderita HIV/AIDS setelah intervensi}

Tabel. 2 Pengukuran Kecemasan setelah terapi

\begin{tabular}{lcc}
\hline Kecemasan & frekuensi & $\%$ \\
\hline Sedang & 3 & $30 \%$ \\
Ringan & 6 & $60 \%$ \\
\hline
\end{tabular}




\begin{tabular}{lcc}
\hline Tidak Cemas & 1 & $10 \%$ \\
\hline Total & 10 & $100 \%$ \\
\hline
\end{tabular}

Hasil pengukuran rata-rata kecemasan setelah intervensi diketahui terdapat perbedaan indeks cemas dari yang sebelumnya $70 \%$ mengalami kecemasan berat dan setelah intervensi menjadi $60 \%$ responden mengalami kecemasan ringan.

Langkah untuk melakukan pelepasan otot reformis adalah dengan cara beristirahat atau duduk di kursi dengan kepala ditegakkan, otot dibiarkan tegang lima samapi tujuh detik kemudian dikendurkan dua belas sampai lima belas detik. Melakukan relaksasi otot progresif secara rutin oleh responden dapat menyebabkan peregangan kardiopulmonari yang dapat meningkatkan bar reseptor dan mengaktifkan kerja saraf parasimpatik dengan mengurangi aktivitas simpatik rasa tegang pada responden $^{[25]}$. Terapi relaksasi otot progresif merupakan pergerakan otot ekstermitas secara berurutan dengan gerakan peregangan dan pelemasan. Manfaat terapi ini adalah meningkatkan mood klien dan fleksibilitas, dan mengurangi keletihan ${ }^{\text {[21]. }}$

Hasil wawancara yang dilakukan peneliti terhadap responden setelah intervensi, sebagian besar responden menyatakan kondisi tidak bisa tenang, takut akan pikiran sendiri, mudah tersinggung, merasa gugup, terbangun di malam hari, bermimpi buruk, dan perasaan depresi menjadi berkurang bahkan menghilang. Responden merasakan ketenangan dalam menjalankan kehidupan sehari-hari dan berusaha untuk selalu berpikir positif terhadap stressor yang dihadapinya.

Hal ini didukung penelitian yang dilakukan oleh Julianti, dkk (2017), terapi peregangan otot progresif yaitu bahwa tingkat kekambuhan kecemasan setelah intervensi pengenduran otot menunjukkan bahwa responden yang tidak mengalami cemas sebanyak 10 orang $(66,7 \%)$ sedangkan responden yang mengalami cemas ringan yaitu 5 orang $33,3 \%$. Setelah melakukan terapi pengenduran otot progresif ternyata kecemasan wanita pasangan usia subur (WPUS) menurun pada dasarnya. Hal ini karena selama intervensi pelepasan otot progresif dapat terjadi peregangan kardiopulmonari yang dapat meningkatkan baroreseptor dan peningkatkan kerja yang dibentuk oleh saraf-saraf para simpatis dengan kerja saraf simpatis sehingga dapat meredam tekanan yang dialami wanita pasangan usia subur (WPUS) di kondisi yang setara atau berlawanan (pengecualian) ${ }^{[21]}$.

\section{Pengaruh relaksasi otot progresif terhadap kecemasan}

Tabel 3Perbedaan Mean sebelum dan sesudah intervensi terhadap tingkat kecemasan

\begin{tabular}{|l|l|l|l|l|}
\hline $\begin{array}{l}\text { Kecemasa } \\
\mathrm{n}\end{array}$ & $\begin{array}{l}\text { Mea } \\
\mathrm{n}\end{array}$ & $\mathrm{SD}$ & $95 \%$ & $\begin{array}{l}\text { pValu } \\
\mathrm{e}\end{array}$ \\
\hline $\begin{array}{l}\text { Sebelum } \\
\text { Setelah }\end{array}$ & $\begin{array}{l}29.9 \\
0\end{array}$ & $\begin{array}{l}5.13 \\
1\end{array}$ & $\begin{array}{l}1.123 \\
-\end{array}$ & 0.000 \\
& $\begin{array}{l}16.5 \\
0\end{array}$ & $\begin{array}{l}3.86 \\
6\end{array}$ & 1.877 & \\
\hline
\end{tabular}

Hasil analisis uji T-dependen diketahui mean sebelum dilakukan terapi relaksasi otot progresif yaitu 29,90 dengan standar deviasi 5,131 sedangkan mean setelah dilakukan terapi relaksasi otot progresif sebesar 16,50 dengan nilai standar deviasi 3,866. Perbedaan mean sebelum dan sesudah intervensi adalah sebesar - 1.340. Hasil pValeu $=0.000(<0.05$ dengan CI 95\%). Hal ini memperlihatkan terdapat pengaruh terapi otot progresif dalam menurunkan kecemasan WPUS penderita HIV/AIDS di Klinik Mawar Kota Bandung. 
Penelitian ini sejalan dengan penelitian Ambarwati, dkk (2020), proses penurunan kecemasan dengan melakukan relaksasi otot di beberapa bagian tubuh, akan mempengaruhi hipotalamus dan menurunkan kinerja sistem syaraf melalui peningkatan kerja saraf parasimpatis. Penurunan ini menimbulkan respon terhadap tekanan darah, metabolisme, respirasi sehingga dapat mengurangi pemakaian oksigen, ketegangan otot, denyut nadi, cemas dan mengatasi stresor ${ }^{[20]}$. Penelitian Lestari (2015), menyatakan bahwa relaksasi otot progresif dapat menurunkan kecemasan pasien pra operasi di Ruang Wijaya Kusua RSUD Dr. Soprapto Cepu ${ }^{[11]}$. Dan penelitian Julianti (2017) pun menyatakan ada pengaruh relaksasi otot progresif terhadap penurunan tingkat kecemasan pada wanita pasangan usia subur (WPUS) ${ }^{[21]}$. Sebagimana teori Dalami (2009) bahwa pengenduran otot dapat menurunkan tingkat kecemasan, stress, takanan darah, dan detak jantung ${ }^{[17]}$.

Respons fisiologis tubuh terhadap kecemasan, ditandai dengan adanya reaksi saling menyerang antar stimulus. Korteks otak mendapat rangsang yang dikirim melalui saraf ke organ adrenal dan melepaskan epineprin yang meningkatkan pernapasan, denyut nadi, dan detak jantung. Reaksi ini memerlukan energi, sehingga pangkreas akan mengeluarkan glukosa sebagai bahan bakar untuk otot, selian itu reaksi kimia memperkuat berubahnya lemak dan protein menjadi gula. Pencernaan tubuh meningkat untuk mengantisipasi penggunaan energi untuk aktivitas fisik.

Pengenduran otot akan memberikan ketenangan yang menyebar ke aliran tubuh. Perkembangan yang terjadi selama dan setelah pengenduran akan mempengaruhi syaraf otonom. Reaksi psikologis dan pengaruh ketenangan yang ditimbulkan oleh pengenduran ini akan mengubah fisiologi dominan menjadi parasimpatis. Situasi tersebut menyebabkan, hipersekresi katekolamin dan kortisol menurun dan memperluas reaksi kimia parasimpatis dan sinapsis seperti DHEA (Dehidroepinandrosteron) dan dopamin. Framework parasismpatis ini pada akhirnya dapat memiliki dampak yang menyenangkan [26].

Mekanisme pengenderuan otot progresif dapat menstimulus sistem sensorik parasimpatis dengan menganimasikan penurunan berbagai kapasitas yang disebabkam sistem sensorik dan meningkatkan setiap kapasitas yang dibuat oleh sistem saraf simpatis ${ }^{[27]}$. Sensasi pengenduran otot akan disampaikan ke pusat saraf untuk membuat Corticotropin Releasing Factor (CFR) yang menstimulasi organ hipofisis untuk memperhebat reaksi kimia, misalnya $\beta$-endorfin, encephalins dan serotonin sehingga dapat melumpuhkan ketegangan, mengurangi penyempitan otot, ketegangan dan nyeri ${ }^{[28] .}$ Secara fisiologis, perasaan tenang ini adalah konsekuensi dari berkurangnya pergerakan RAS (Reticular Activating System) dan noreepineprine karena berkurangnya kerja rangka batang otak besar. Reaksi pengenderuan otot terjadi karena kerja sistem sensorik otonom parasimpatis dianimasikan menyebabkan perubahan yang dapat membatasi kerja sistem sensorik otonom melalui oksigen yang berkurang, seperti gelombang alfa di otak besar sehingga kecemasan berkurang ${ }^{[16]}$.

Seseorang yang mampu mengendalikan keadaan psikologisnya secara relaks, maka otot tubuh relaks dan tenang, akibat peningkatan oksigen dalam darah. Terapi otot ini merupkan kombinasi Teknik relaksasi nafas dalam yang membuat tubuh menjadi terasa nyaman. 
Hasil wawancara yang dilakukan peneliti kepada responden tentang kondisinya setalah dilakukan terapi pengenduran otot menyatakan bahwa, sebagian responden merasakan adanya perubahan pada tubuhnya, seperti lebih nyenyak ketika tidur, keluhan keluhan sakit yang dirasakan terasa menghilang, dan emosi serta pikiran mereka menjadi kearah yang positif, sehingga apa yang dialami mereka sebelumnya seperti kondisi tidak bisa tenang, takut akan pikiran sendiri, mudah tersinggung, merasa gugup, terbangun di malam hari, bermimpi buruk, dan perasaan depresi menjadi berkurang bahkan menghilang.

\section{KESIMPULAN}

Relaksasi otot progresif berpengaruh pada tingkat kecemasan WPUS penderita HIV/AIDS. Peneliti menyarankan kepada responden untuk melakukan pengenduran otot progresif secara rutin apabila mereka mulai merasakan kecemasan

\section{DAFTAR PUSTAKA}

[1] Kemenkes RI, "InfoDatin-HIV-AIDS," 2020.

[2] Kementerian kesehatan RI, "Infodatin HIV AIDS," 2020. [Online]. Available: http://www.depkes.go.id/resources/dow nload/pusdatin/infodatin/Infodatin AIDS.pdf.

[3] BKKBN, Pemantauan Pasangan Usia Subur Melalui Mini Survei Indonesia. Jakarta: BKKBN, 2013.

[4] N. T. Kancheva Landolt, S. Lakhonphon, and J. Ananworanich, "Contraception in HIV-positive female adolescents," AIDS Res. Ther., vol. 8, pp. 1-11, 2011, doi: 10.1186/17426405-8-19.
[5] S. Oktaseli, M. Rachmawati, and A. Suliaty, "Hubungan Karakteristi Pasien, Perilku Beresiko Dan Ims Dengan Kejadian Hiv/Aids Pada Wanita Usia Subur Di Klinik Vct Upt Blud Puskesmas Meninting Tahun 20152017," J. Med. (Media Inf. Kesehatan), vol. 6, no. 2, pp. 133-154, 2019, doi: 10.36743/medikes.v6i2.189.

[6] V. I. Abdullah, W. Permadi, and H. Susiarno, "Differences of Quality of Life Between Men and Women of Reproductive Age Suffering Human Immunodeficiency Virus Infection By Using the Instrument Whoqol-Hiv Bref in Clinic Mawar Bandung City," Repository2.Stikesayani.Ac.Id, vol. 3, no. 1, pp. 1-7, 2019, [Online]. Available: http://repository2.stikesayani.ac.id/inde x.php/isgh3/article/download/304/261.

[7] D. K. Nugrahaeni, N. E. Mauliku, and S. N. Hendayani, "Transplacental Transmission of HIV/AIDS In Houeswives With HIV Positive," vol. 3, no. 1, pp. 2012-2015, 2019.

[8] R. Ethel, W. AS, and M. Sofro, "Hubungan Tingkat Kecemasan Dengan Kualitas Hidup Pasien Hiv/Aids Di Rsup Dr. Kariadi Semarang," J. Kedokt. Diponegoro, vol. 5, no. 4, pp. 16231633, 2016.

[9] E. A. Yudiati and E. Rahayu, "Hubungan Antara Coping Stres Dengan Kecemasan Pada Orang-Orang Pengidap Hiv/Aids Yang Menjalani Tes Darah Dan Vct (Voluntary Counseling Testing)," Psikodimensia, vol. 15, no. 2, p. 337, 2017, doi: 10.24167/psiko.v15i2.995.

[10] D. F. Annisa and I. Ifdil, "Konsep Kecemasan (Anxiety) pada Lanjut Usia (Lansia)," Konselor, vol. 5, no. 2, p. 93, 2016, doi: 10.24036/02016526480-000. 
[11] K. Lestari and A. Yuswiyanti, "Pengaruh Relaksasi Otot Progresif terhadap Penurunan Tingkat Kecemasan pada Pasien Pre Operasi di Ruang Wijaya Kusuma RSUD DR. R Soeprapto Cepu," J. Keperawatan Matern., vol. 3, no. 1, p. Halaman 2732, 2015, [Online]. Available: https://jurnal.unimus.ac.id/index.php/JK Mat/article/view/4017.

[12] Rihiantoro,T., Handayani R.S., Wahyuningrat, N.L.M., Suratminah, "Pengaruh Tehnik Relaksasi Otot Progresif terhadap Kecemasan pada Pasien Pre Operasi," Vol 14 (2), pp. 129-135, 2018.

[13] E. Lestiawati and A. Liliana, "Relaksasi Otot Progresif Dan Autogenik Untuk Yogyakarta Progressive Muscle Relaxation and Autogenic To Reduce Adolescent Stress At Smkn 1 Depok Sleman," Semin. Nas. UNRIYO [November], pp. 1-10, 2019.

[14] H. . Kaplan and B. . Saddock, Ilmu Kedokteran Jiwa Darurat. Jakarta: Widya Medika, 1998.

[15] Nurhalimah, Keperawatn Jiwa. Jakarta: Kementrian Kesehatan RI, Pusdik SDM Kesehatan, 2016.

[16] D. Hawari, Manajemen Stres, Cemas dan Depresi. Jakarta: Gaya Baru FKUI, 2011.

[17] D. Ermawati, Susilawati, P. Farida, and E. Banon, Asuhan Keperawatan Jiwa dengan Masalah Psikososial. Jakarta: Trans Info Media, 2009.

[18] T. Setyoadi, Terapi Modalitas Keperawatan dan Klien Psikogeriatik. Jakarta: Salemba Medika, 2015.

[19] N. Manurung, Terapi Reminiscence. Jakarta: TIM, 2016.

[20] P. Ambarwati and E. Supriyanti,
"Relaksasi Otot Progresif Untuk Menurunkan Kecemasan Pada Pasien Asma Bronchial," J. Manaj. Asuhan Keperawatan, vol. 4, no. 1, pp. 27-34, 2020, doi: 10.33655/mak.v4i1.79.

[21] H. . Julianti, R. . Kartadinata, R. Handoyo, and Noviolita, "Efek Latihan Relaksasi Otot Progresif Terhadap Perbaikan Gejala Klinis, Kecemasan, Hasil Elektromiografi dan Kualitas Hidup Pasien Spasmofilia," vol. 2, no. 1, pp. 9-19, 2017.

[22] A. D. K. Sari and Subandi, "Pelatihan teknik relaksasi untuk menurunkan kecemasan pada primary caregiver penderita kanker payudara," Gadjah Mada J. Prof. Psychol., vol. 1, no. 3, pp. 173-192, 2015.

[23] D. K. Nugrahaeni and N. E. Mauliku, Metodologi Penelitian Kesehatan. Bandung: Stikesayani Pres, 2011.

[24] D. M. S. K. Dewi, L. P. L. Wulandari, and D. N. Wirawan, "Determinan Sosial Kerentanan Perempuan Terhadap Penularan Ims Dan Hiv," J. Public Heal. Res. Community Heal. Dev., vol. 2, no. 1, p. 22, 2019, doi: 10.20473/jphrecode.v2i1.16250.

[25] A. Muttaqin and K. Sari, Gangguan Gastrointestional: Aplikasi Asuhan Keperawatan Medikal bedah. Salemba Medika, 2011.

[26] H. Purwanto, Keperawatan Medikal Bedah II, Edisi 1. Jakarta: Kementrian Kesehatan RI, Pusdik SDM Kesehatan, 2016.

[27] R. J. Jannah, A. Jatimi, M. J. Azizah, Z. Munir, and H. F. Rahman, "Kecemasan Pasien COVID-19: A Systematic Review," J. Penelit. Kesehat. Suara Forikes, vol. 11, no. 2, pp. 33-37, 2020.

[28] E. Kurniawati, A. Badi'ah, and Surantono, "Efektifitas Teknik 
Relaksasi Nafas Dalam Dan Relaksasi Otot Progresif Terhadap Penurunan Tingkat Kecemasan Pada Pasien Pre Operasi Dengan General Anestesi Di Rsu Pku Muhammadiyah Bantul," Poltekkes Kemenkes Yogya, pp. 10-43, 2019, [Online]. Available: http://eprints.poltekkesjogja.ac.id/1134/ 4/4. Chapter 2.pdf. 